\title{
Acronyms, Abbreviations, and Foreign Terms
}

CPK Church of the Province of Kenya (Anglican)

FORD Forum for the Restoration of Democracy

GEMA Gikuyu, Embu, and Meru Association

GSU Government Services Unit

ICJ International Commission of Jurists

KADU Kenya African Democratic Union

KANU Kenya African National Union

KASA Kenya African Socialist Alliance

KAU Kenya African Union

KCA Kikuyu Central Association

KCGA Kenya Coffee Growers' Association

KIA Kenya Institute for Administration

KLFA Kenya Land Freedom Army

KPCU Kenya Planters' Cooperative Union

KPU Kenya People's Union

KTDA Kenya Tea Development Authority 
LSK

MVOA

NCCK

NTZDC

PCEA

KSh

aboi

jua kali

harambee

majimboism

matajiri

matatu

nyayo

shamba

ujamaa

wananchi
Law Society of Kenya

Matatu Vehicle Owners Association

National Council of Churches of Kenya

Nyayo Tea Zones Development Corporation

Presbyterian Church of East Africa

Kenyan shilling $(1 \mathrm{KSh}=100$ cents $)$

Kikuyu term for squatters or farming households without their own land

"hot sun": a term for the informal sector of the economy in Kenya

Swahili for "let's pull together"; self-help development

regionalism

Swahili for "the wealthy" or "the rich"

a privately owned small truck converted to transport passengers commercially

Swahili for "follow in the footsteps"

a plot of land for farming

Swahili for "family"; the name given to the villagization and rural development program adopted in Tanzania in 1967

the common people 